\title{
Study of the Affinity of Extracts from Dromedary Abomasums for Cow's Milk
}

\author{
Boudjenah $\mathrm{HS}^{1 *}$, Isselnane $\mathrm{S}^{2}$ and Mati $\mathrm{A}^{2}$ \\ ${ }^{1}$ University Kasdi Merbah Ouargla, Algéria \\ ${ }^{2}$ University Mouloud Mammeri de Tizi Ouzou, Algérie
}

Submission: October 18, 2016 Published: November 17, 2017

*Corresponding author: Boudjenah HS, University Kasdi Merbah Ouargla, Algéria, Email: salihaboudjenahharoun@yahoo.fr

\begin{abstract}
Although rennet is still the most used coagulating enzyme in cheese, its production has been growing worldwide shortage. This shortage is primarily due to a growing increase in the production and consumption of cheese, and the inability to increase in parallel the production of rennet. This shortage has caused very large fluctuations in its price). To overcome these obstacles, much research has been undertaken to find effective and competitive substitutes used industrially. For this, the selection of a local production of rennet substitute is desirable. It would allow a permanent supply with limited dependence on imports and price fluctuations. Investigations conducted by our research team showed that extracts coagulants from the stomachs of older camels are characterized by a coagulating power than those from younger camels.

The objective of this work is to study the possibility of substituting commercial rennet coagulant by gastric enzymes from adult camels for coagulation bovine milk. Excerpts from the raw camel coagulants obtained are characterized through their teneures proteins and clotting and proteolytic activities. Milk clotting conditions by the action of these extracts were optimized. Milk clotting time all treated with enzyme preparations and under different conditions was calculated. Bovine rennet has been used for comparison. The results show that crude extracts from gastric adult camel can be good substituting bovine rennet.
\end{abstract}

Keywords: Camel; Milk; Cheese; Gastric extracts; Coagulation; Algeria

\section{Introduction}

Making cheese development is often achieved through the use of coagulating enzymes whose tonnage and diversity are constantly changing. Different proteases capable of hydrolyzing the Kapa casein may cause coagulation of the milk and allow the manufacture of derivates products. However, this condition is not always sufficient for widespread use in milk processing industry because the ratio of clotting activity and the proteolytic activity are decisive for the good choice of the enzyme. Rennet is an enzyme preparation extracted from young calves fed milk curd (and sacrificed before weaning) is the agent most used for milk coagulation [1]. Although this coagulating enzyme is still the most used in cheese, its production has been growing worldwide shortage. This shortage is primarily due to a growing increase in the production and consumption of cheese, and the inability to increase in parallel the production of rennet. This shortage has caused very large fluctuations in its price [2]. Today its use is facing the major constraint sacrifice of young calves and therefore much getting increasingly important enzyme likely to meet growing needs.
Indeed, the increase in world milk production and the overall increase in cheese consumption have accentuated this handicap and have promoted a particular research effort to explore alternative ways of rennet by other coagulating enzymes

of original animal, plant and microbial. Algeria, which knows a total dependence of our dairies in manufacturing ingredients, must participate in this effort especially since domestic production of raw milk and consumption of dairy produce are experiencing a substantial increase in recent years. In this regard, we proposed to see how the isolated enzyme extracted from adult dromedaries could be a substitute of bovine rennet to coagulate the bovine milk

\section{Experimental Part}

\section{Abomasal tissues}

The camel abomasal tissues were obtained from camel slaughterhouse of Ouargla, Algeria. The abomasums were obtained from adult camels. The abomasal tissues were cleaned 
with running water, defatted, cut in slices, packaged in plastic bags and frozen at- $18{ }^{\circ} \mathrm{C}$ Commercial enzymes. Bovine pepsin in powder form and bovine rennet containing $80 \%$ chymosin and 20\% pepsin were purchased from Texel-Poulenc (France).

\section{Milk samples}

The milk samples were collected in sterile bottles and delivered in a cooler with ice to the laboratory.

\section{Extraction of gastric enzymes from camel abomasal tissues}

The method of gastric enzymes extraction from bovine abomasal tissue as described by [3] was used with minor modifications. The steps involved were:

a. Soaking of a known weight of sliced abomasal tissue in 1.25 volume of $0.2 \mathrm{M} \mathrm{HCL}$ at $42^{\circ} \mathrm{C}$ temperature for 60 minutes and filtration through a paper filter.

b. Clarification: of the extract using $1 \%(\mathrm{~V} / \mathrm{V})$ of $1 \mathrm{M}$ solution of $\mathrm{Al}_{2} \mathrm{SO}_{4}$ and $5 \%$ of a $1 \mathrm{M}$ solution of $\mathrm{Na}_{2} \mathrm{SO}_{4}(1 \mathrm{M})$ heated to $42{ }^{\circ} \mathrm{C}$, After filtration a yellowish clarified solution was obtained.

c. Concentration: a double solution of saturated $\mathrm{NaCl}$ containing $1 \%(\mathrm{w} / \mathrm{w})$ of concentrated $\mathrm{HCl}$ was added to the known weight of the abomasal tissue.

After mixing, the mixture was put to rest for one hour, centrifuged at $2100 \mathrm{~g}$ for 20 minutes, the supernatant was discarded and the wet weight was recorded followed up by adding $10 \%(\mathrm{w} / \mathrm{v})$ of distilled water. The $\mathrm{pH}$ of the concentrated filtrated was adjusted to 5.5 with $\mathrm{Na}_{2} \mathrm{HPO}_{4}$ at $42{ }^{\circ} \mathrm{C}$. The extracted camels' gastric enzymes obtained were assigned the label DCE (Dromedary's Coagulant Extract. The fresh DCE analyzed, and some samples were stored at $4{ }^{\circ} \mathrm{C}$ with the addition of $10 \%(\mathrm{v} / \mathrm{v}$ ) of thymol and $10 \% \mathrm{NaCl}$ for preservation purpose.

\section{Protein analysis of the DCE}

The method of [4] was used to determine the protein content of the gastric enzyme extracts of camels. The amount of proteins $(\mathrm{g} / \mathrm{ml})$ was obtained using a standard curve based on bovine serum albumin (BSA).

\section{Clotting activities of the DCE}

The method of [5] was used. The main steps were the following. The standard substrate was the "low heat" milk powder at $10 \%(\mathrm{w} / \mathrm{v})$ solution in $\mathrm{CaCl} 2(0.01 \mathrm{M})$ solution, and the $\mathrm{pH}$ was adjusted to 6.5 with $0.1 \mathrm{NNaOH}$. The DCE was added at $1 \mathrm{ml} / 10 \mathrm{ml}$ of standard substrate and mixed manually and incubated in a water bath at $30^{\circ} \mathrm{C}$. After thoroughly mixing three times, the clotting time zero started. The clotting activity equation as reported by [5] in rennet units (RU) was used:

$$
\mathrm{RU}=10 \times \mathrm{V} / \mathrm{Tc} \times \mathrm{Q}
$$

RU: rennet unit

\author{
V: volume of standard substrate $(\mathrm{ml})$ \\ Q: volume of DCE (ml) \\ Tc: time of clotting (sec) \\ Clotting strength
}

The clotting activity of the DCE was also reported in clotting strength of Soxhlet (F) based on the equation of [6].

F: Clotting strength of Soxhlet.

\section{Proteolytic activity}

The method of [7] for the proteolytic activity of the DCE was used. In addition the clotting activity was optimized by using the method of [8]. Bovine milk coagulation was carried out by using the method of [9]. However, the flocculation time was measured visually by the method of [10] at different $\mathrm{pH}$ and temperatures. The flocculation time is the time between the addition of coagulating enzyme of the appearance of flakes visible to the naked eye. This method consists in the introduction of $10 \mathrm{ml}$ of milk in a test tube with a fixed concentration of $\mathrm{CaCl}_{2}$ solution and incubated at the desired temperature after the addition of a coagulant enzyme concentration. The concentration of the enzyme is such that the flocculation of milk to $\mathrm{pH}=6.3$ (a concentration of $0.01 \mathrm{M} \mathrm{CaCl}_{2}$ and $30{ }^{\circ} \mathrm{C}$ ) occurs after about 15 minutes.

\section{Optimization of the flocculation time}

The flocculation time ( $\mathrm{ft}$ ) of bovine milk was optimized at four different $\mathrm{pH}(5.5,6.0,6.3$ and 6.6) and at three different temperatures $\left(30,37\right.$ and $\left.39^{\circ} \mathrm{C}\right)$. The mixture is adjusted to the desired $\mathrm{pH}$ with $0.1 \mathrm{M} \mathrm{HCl}$, incubated at the desired temperature [10].

\section{Statistical analysis}

All experiments were performed with three replicates each. All data are reported as means with standard deviations. An analysis of variance (ANOVA) was applied to assess differences among the "Dromedary's Coagulant Extract" (DCE) and the commercial enzymes by using SPSS (Statistical Package for the Social Sciences) software version 18.0.

\section{Results and Discussion}

\section{Characterization of gastric extract enzymes}

The protein average in $\mathrm{g} / \mathrm{l}$ of the DCE was 1.44.

\section{Clotting and proteolytic activities}

The clotting activity was the highest for the DCE compared to the two commercial enzymes, rennet and pepsin bovine. They were significantly different at $\mathrm{P} \leq 0.05$ (Table 1 ). DCE showed a lower proteolytic activity than Rennet bovine (Rb) (1.34 \pm 0.015$)$. However its proteolytic activity was close to that of the bovine pepsin (0.84 \pm 0.015$)$. An increase in absorption at this wavelength $(280 \mathrm{~nm})$ could be fully attributed to the formation of unspecific 
cleavage products [11]. Observed that the proteolytic activity of enzymes increased with higher incubation temperatures and also when the $\mathrm{pH}$ of the assays was decreased. In cheese production, the desired enzyme should have high clotting activity and low proteolytic activity [9]. DCE could be considered as a good source of enzyme for cheese making. The high clotting activity and low proteolityc activity as shown by DCE A are a pre-requisite for an acceptable rennet substitute $[12,13]$ for making cheese.

Table 1: Proteolytic activity of the enzymatic preparations.

\begin{tabular}{|c|c|c|}
\hline $\begin{array}{c}\text { Enzymatic } \\
\text { Preparations }\end{array}$ & $\begin{array}{c}\text { Clotting Activity } \\
\text { (RU) }\end{array}$ & Proteolytic Activity \\
\hline DCE & $0.410 \mathrm{a} \pm 0.020$ & $0.84 \mathrm{a} \pm 0.015$ \\
\hline Pepsin bovine $(\mathrm{Pb})$ & $0.123 \mathrm{~b} \pm 0.002$ & $0.84 \mathrm{a} \pm 0.020$ \\
\hline Rennet bovine $(\mathrm{Rb})$ & $0.164 \mathrm{c} \pm 0.002$ & $1.34 \mathrm{~b} \pm 0.015$ \\
\hline
\end{tabular}

Except for the bovine pepsine (Figure 1), the time required to reach the flocculation of bovine milk was short. These results are in agreement with those of [11]. The flocculation time of DCE was shorter for bovine milk than pepsin bovine (P-b) but close to rennet bovine (Pr-b). This finding is in agreement with other researchers $[14,15]$. In order to define the affinity of the enzyme preparations to the substrate (cow milk), the flocculation time of bovine milk was determined. Figure 1 shows that the DCE demonstrated an affinity for this milk, indicating that this enzyme would be suitable for bovine milk coagulation.

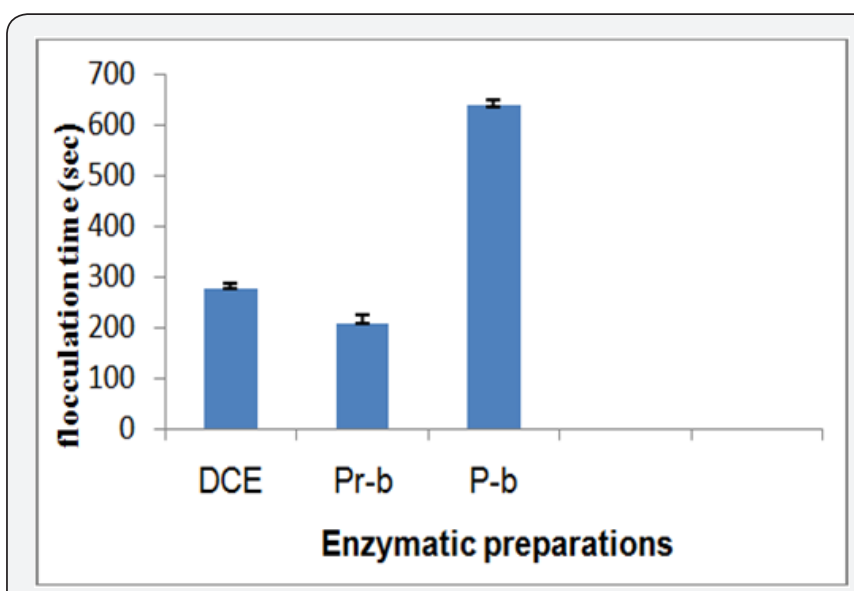

Figure 1: Effect of the enzymatic preparations on the flocculation time of bovine milk.

\section{Effect of $\mathrm{pH}$ on the flocculation time}

Milk clotting activity was influenced by the $\mathrm{pH}$ of the milk at the stage. All enzyme preparations exhibited almost a linear curve with an increased $\mathrm{pH}$ from 5.5 to 6.6. The optimum $\mathrm{pH}$ for clotting cow milk by the DCE was at 5.5. Also it appeared that DCE was less affected by the increased $\mathrm{pH}$ (Figure 2). The $\mathrm{pH}$ of the milk for rapid flocculation is very important during cheese making since the acidification by the lactic acid bacteria helps the enzyme activity in which the enzyme is a protease having an optimum activity around $\mathrm{pH}$ 5.5. This contributes to the destabilization of the casein micelles $[10,16]$ found that the effect of $\mathrm{pH}$ of milk on flocculation was very sensitive and apparent, thus the flocculation time is further reduced if the renneting $\mathrm{pH}$ is far below the normal $\mathrm{pH}$ of milk. This is in agreement with the findings of Ramet $[17,18]$, that all clotting cheese enzymes are acid protease, that their activity is optimum at $\mathrm{pH} 5.5$ and that the kappa casein presents stability at $\mathrm{pH}$ 5.6. This is not the case for camel milk since the slow $\mathrm{pH}$ drop in camel milk is not conducive to the clotting activity $[17,19]$. The effect of temperature on the flocculation time of the enzymes on cow milk is shown in Figure 3.

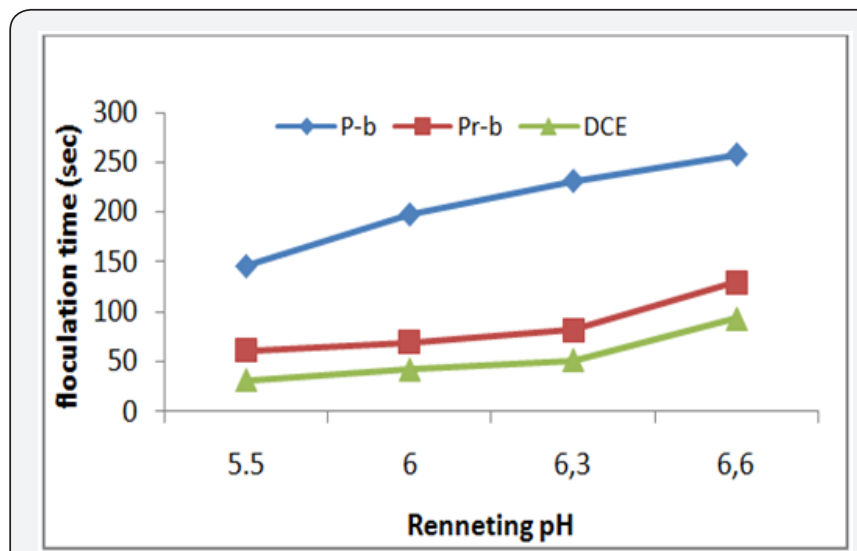

Figure 2 : Effect of renneting $\mathrm{pH}$ of cow milk on the flocculation time.

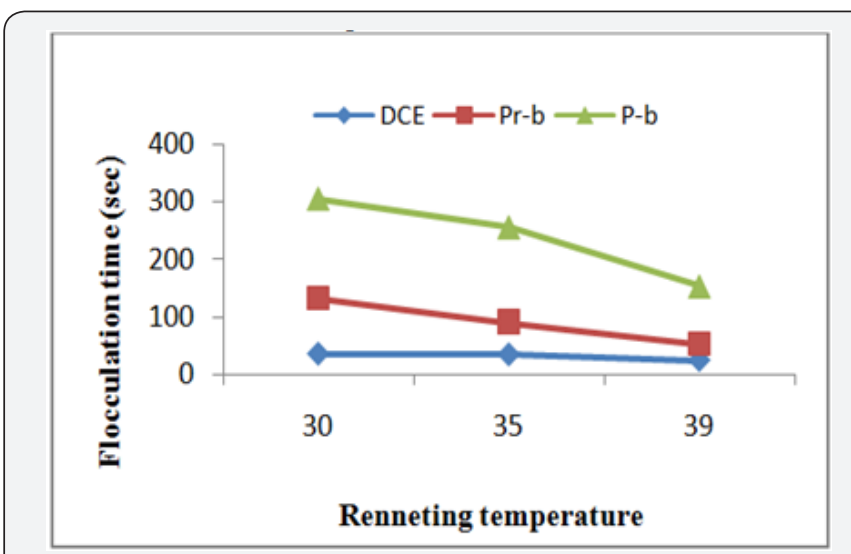

Figure 3 : Effect of temperature of bovine milk on the flocculation time.

Temperatures $\left(30,37\right.$ and $\left.39{ }^{\circ} \mathrm{C}\right)$ led to a decrease in flocculation time by all these enzymes. However, the shortest flocculation time was obtained with DCE, indicating that DCE could be the more stable enzyme but all the enzymes showed an optimum activity and flocculation time at $39^{\circ} \mathrm{C}$ (Figure 3). This is in line with the data reported by Ramet $[17,18]$, that the optimum temperature of most clotting enzymes were around $40-50{ }^{\circ} \mathrm{C}$, but beyond these values there was a progressive denaturation of the enzyme and at $65{ }^{\circ} \mathrm{C}$ there was no activity. Similarly, [20] reported that the proteolytic activity of buffalo chymosin treated 
at different temperatures exhibited a relatively stable proteolytic activity curve up to a temperature of $55{ }^{\circ} \mathrm{C}$ after which there was a decline of the activity. Measuring the flocculation time at different temperature suggested which enzyme would be more suitable for cow milk clotting in a short period as well as the manufacture of various types of cheeses, such as soft, semi-hard and hard cheese.

Overall, based on the data reported and in line with other researchers' reports [1,18,21-23], this study proposes an optimum temperature at $39^{\circ} \mathrm{C}$ and a pH of 5.5 for an optimum clotting activity and flocculation time using gastric enzymes extracted from camels. From the results obtained it can be concluded that the crude enzymes extracted from old camels coagulate cow milk. Elsewhere the results of the study undertaken by [23], suggest that camel chymosin can be used successfully to make Cheddar cheese with lower levels of proteolysis but with good flavor. This study focused primarily on the coagulation step that represents the key step in making cheese but additional studies are necessary on the performance and characteristics of the cheese obtained with these enzymes.

\section{Conclusion and Outlook}

The non-purified enzyme preparations (DCE) obtained from the older camels showed a good coagulation activity on cow milk. Flocculation time data showed that the DCE and bovine rennet (Pr-b) had good specificity towards bovine casein. In addition, the short flocculation time obtained for DCE of older camels at an optimum temperature at $39^{\circ} \mathrm{C}$ and a $\mathrm{pH}$ of 5.5 was encouraging since older camels are more available for slaughter in Algeria. Therefore the production of DCE from older camels could be an excellent substitute for the commercial chymosin for cheese making. It was recommended that additional research be conducted to purify the extract, to characterize the extract using electrophoreses.

\section{References}

1. Etudes DMJ (1990) Les enzymes utilisés en industrie laitière. In: Lait et dromadaire en Tunisie. Revue dElevage et de Médecine Vétérinaire des Pays Tropicaux 42:113-115.

2. Valles E, Furet JP, Cuvellier (1977) Etude des caillettes des bovins à l'état ruminant pour l'obtention d'extraits coagulants à base de pepsine bovine : méthodes d extraction. Lait 61:601-617.

3. Lowry OH, Rosebrough NJ, Farr AL, Randall RJ (1951) Protein measurement with folin phenol reagent. J Biochem 193(1): 265-275.

4. Berridge NJ (1952) An improved method of observing the clotting of milk containing rennin. J Dairy Res 19(3): 328-332.

5. Bourdier JF, Luquet FM (1981) Dictionnaire Laitier. Tec Doc Lavoisier, France.
6. Bergere JL, Lenoir J (1997) Les accidents de fromagerie et les défauts des fromages. In: ECK André, Gillis JC (Eds.), Le fromage Troisiéme. Tec Doc Lavoisier, France, pp. 509-541.

7. Shamet KM, Brown RJ, Mc Mahon DJ (1992) Proteolytic activity of some milk clotting enzymes on caseins. J Dairy Sci 75(6): 1373-1379.

8. Ramet JP (1997) Les Agents de la transformation du lait. In: André ECK, Gillis JC (Eds.), Le fromage Troisième ( $3^{\text {rd }}$ edn.), Tech Doc Lavoisier, France, pp. 165-174.

9. Lenoir J, Remeuf F, Schneid N (1997) Laptitude du lait à la coagulation par la pressure. In: André ECK, Gillis JC (Eds.), Le fromage Troisième. Tech Doc Lavoisier, France, pp. 229-255.

10. Kappeler SR, van der Brink HJM, Rahbek-Nielsen H, Farah Z, Puhan Z, et al. (2006) Characterization of recombinant camel chymosin reveals superior properties for the coagulation of bovine and camel milk. Biochemical and Biophysical Research Communications 342(2): 647654.

11. Fox PF (1969) Milk clotting and proteolytic of rennet, and of bovine pepsin and porcine pepsin. J Dairy Res 36(3): 427-433.

12. Elagamy EI (2000a) Physico-chemical, molecular and immunological characteristics of camel calf rennet: a comparison with cow's and buffalo rennet. J Dairy Res 67(1): 73-81.

13. Ramet JP (1994) Les aspects scientifiques et technologiques particuliers de la fabrication de fromage au lait de dromadaire. Actes du Colloque: Dromadaires et chameaux animaux laitiers. Nouakchott, Mauritanie, pp. 24-26.

14. Siboukeur O, Mati A, Hessas B (2005) Amélioration de laptitude à la coagulation du lait camelin (camelus dromedarius): utilisation dextraits enzymatiques coagulants gastriques de dromadaires. Cahiers agricultures 5: 473-478.

15. Chazarra S, Sidrach L, Lopez-Molina D, Rodrıguez-Lopez JN (2007) Characterization of the milk-clotting properties of extracts from artichoke (Cynara scolymus L.) flowers. Intern Dairy J 17: 1393-1400.

16. Ramet JP (1985) Study of enzymatic coagulation of camel milk in Saudia-Arabia. Mission Report, FAO, pp. 1-73.

17. Ramet JP (1993) La technologie des fromages au lait de dromadaire (Camelus dromedarius). Etude FAO production et sante' animales 113. Rome, Italy, p. 118.

18. Ramet JP (2001) The technology of making cheese from camel milk (Camelus dromedariue), No.113, FAO, Rome, Italy.

19. Mohanty AK, Mukhopadhyay UK, Kaushik JK, Grover S, Batish VK (2003) Isolation, purification and characterization of chymosin from riverine buffalo (Bubalos bubalis). J Dairy Res 70(1): 37-43.

20. Farah Z, Bachmann MR (1987) Rennet coagulation properties of camel milk. Milchwissenschaft 42(11): 689-692.

21. Mehaia MA (1992) Studies on camel milk coagulation using soluble and immobilized pepsin. Egyptian J Dairy Sci 20: 31-40.

22. Thouvenot C (1997) Le fromage dans lalimentation. In: ECK André, Gillis JC (Eds.), Le fromage. Troisième Tec Doc Lavoisier, France, pp. 736-740.

23. Bansal N, Drake MA, Piraino P, Broe ML, Harboe M, et al. (2009) Suitability of recombinant camel (Camelus dromedarius) chymosin as a coagulant for Cheddar cheese. International Dairy Journal 19: 510-517. 
Your next submission with Juniper Publishers will reach you the below assets

- Quality Editorial service

- Swift Peer Review

- Reprints availability

- E-prints Service

- Manuscript Podcast for convenient understanding

- Global attainment for your research

- Manuscript accessibility in different formats

( Pdf, E-pub, Full Text, Audio)

- Unceasing customer service

Track the below URL for one-step submission https://juniperpublishers.com/online-submission.php 